\title{
THE IMPACT OF ACTIVE CONDUCTORS ON CZECH AND HUNGARIAN LIGHTNING PROTECTION LEGISLATION
}

\author{
Jan Mikešs $\check{S}^{a * *}$, Marcela Efmertováa ${ }^{a}$, Norbert SzedeniK $^{b}$, JiŘí KutáČc ${ }^{c}$ \\ ${ }^{a}$ Faculty of Electrical Engineering Czech Technical University in Prague, Technická 2, CZ-16627 Prague, Prague \\ 6, Czech Republic \\ ${ }^{b}$ Department of Power Engineering Budapest University of Technology and Economics Müegyetem rkp. 3, \\ H-1111 Budapest, Budapest, Hungary \\ ${ }^{c}$ Union of Court Experts, expert in the field of electrical engineering and electroenergetics, specialization in \\ lightning protection and surge phenomena, Prague, Czech Republic \\ * corresponding author: mikes.jan@fel.cvut.cz
}

\begin{abstract}
This paper summarizes the developmental conditions for the emergence of protection against lightning. It reviews the legislation especially in the Czech Republic over the last 15 years, and its application for active lightning conductors. The paper presents examples of the damage caused by lightning strikes on buildings protected by ESE lightning rods constructed using the French national standard NFC 17-102 [1] and STN 341391 [2]. Installation of lightning conductors based on these standards is not, however, in accordance with the valid legislation in the Czech Republic and Hungary. In response to a growing number of ESE installations in the Czech Republic, it is vital to inform both the broader professional publc and the lay public of cases involving failures of this type of lightning conductor.
\end{abstract}

KEYWORDS: lightning protection; ESE, active lightning conductors, Czech Republic, Hungary.

\section{INTRODUCTION}

Lightning is a natural phenomenon, known and unchanged for centuries, with effects that can have fatal consequences not only for immovable and movable assets, but also for people [9]. Underestimating the effects of lightning can lead to building fires (due to higher peak current), the destruction of electrical and electronic equipment (lower peak current), injury or even death.

Nowadays, lightning conductors (lightning rods) are in widespread use as protection against lightning strikes, but the path to their practical application was not easy. From ancient times, people had noted which places were more exposed to lightning strikes and also the consequences of these strikes. Lightning was described as an electrical phenomenon in the 17th century 22. Subsequently, the English physicist Stephen Gray (1670-1736) was the first to distinguish between non-conductive and conductive materials [22]. His research was used to build the first lightning rods based on the identified physical principles of lightning. In the Czech lands, the Premonstratensian canon Václav Prokop Diviš (1696-1765) took up this idea in the mid 18th century, and built the first weather machine $[21,35]$ in the town of Přímětice. Diviš believed that several hundred pieces of metal stored in boxes in the corona of a roughly $40 \mathrm{~m}$ high weather machine would suck the electricity from the clouds and prevent the discharge of lightning. The lightning conductor in Přímětice functioned as a lightning rod with leads connected to a metal cone buried in the ground.
Elsewhere in the world, Benjamin Franklin (17061790) [23] dealt with a similar problem. His letter dated 29th of July 1750 to his friend Peter Collinson, a London merchant and a fellow of the Royal Society, shows that he was already thinking about the use of a lightning rod to protect property and people's lives. He wrote: "... from what I have observed through experiments, I am of the opinion that houses, ships, and even towns and churches may be effectually secured from the stroke of lightning by their means; for if, instead of the round balls of wood or metal, which are commonly placed on the tops of the weathercocks, vanes or spindles of churches, spires or masts, there should be put a rod of iron 8 or 10 feet in length, sharpen'd gradually to a point like a needle, and gilt to prevent rusting, or divided into a number of points, which would be better, the electrical fire would, I think be drawn out of a cloud silently, before it could come near enough to strike". In 1751, when the London Royal Society refused to publish Franklin's conclusions, Collinson at his own expense issued the statement Experiments and Observations on Electricity made by B. Franklin, which was based on Franklin's letters [25].

In describing his lightning rod, Benjamin Franklin commented in 1767: "... the rod either prevents the lightning strike from the cloud or if there is a strike it safely diverts it from the building". 25] Franklin set the basic prerequisite for the mass expansion of lightning rods for the specific protection of structures and people against lightning. Franklin came to this conclusion on the basis of a lighthouse protected by a 
lightning rod in Plymouth. In 1766, Franklin mounted a lightning rod on this lighthouse, which was directly exposed to the elements. Plymouth lighthouse was the first important reference building. It was located on a major trade route, so information on the use of the lightning rod and its indisputable advantages quickly became known.

The first lightning conductor appeared in the Czech lands in 1775 , on a chateau in the town of Měšice $u$ Prahy 22, which was owned by the Nostic family. At the end of the 18th century and early in the 19th century, the use of lightning conductors was approved by members of Patriotic-economic companies both in Bohemia and in Moravia. Another lightning conductor was placed in 1776 on a fortress in Prague Vyšehrad 22, on the local powder store. Iron chains retracted into the river Vltava below Vyšehrad hill were used to ground the lightning rod.

During the reign of the Habsburgs, whose empire the Czech lands formed part of, a legislative basis for the construction of lightning rods was hastily created in the 1760s in Brescia, in Lombardy, Italy, in response to an unfortunate event. There, the bastion in San Nazareth, where $90000 \mathrm{~kg}$ of gunpowder was stored, was struck by lightning. There was an explosion and a large part of the city was destroyed in 1769, killing 3000 people 22 . As a result of this disaster, Queen Maria Theresa ordered that all stocks of ammunition in the monarchy be equipped with lightning protection. This led to problems similar to those of today, where builders of lightning rods did not have suitable construction materials for the devices. This predicament was described in 1778 by Joseph Stepling, who was preparing a lightning rod for a church in Polička.

In 1794, the German physicist, physician and economist Johann Heinrich Albert Reimarus (17291814) published in Hamburg the work Ausführliche Vorschriften zur Blitz-Ableitung an allerley Gebäuden (Detailed rules for the discharge of lightning for buildings of all types), i.e. in a way the first regulations for lightning conductors [24]. Buildings should be protected from the roof, whether they are made of wood or stone. The roof should be under the protection of the superstructure, chimneys and turrets. Other buildings, gazebos, etc. should be covered with metal parts connected in such a way that in the event of a lightning strike to any place the lightning would be led down the conductors. These should be made mainly of lead or copper strips $3-$ 6 inches in width, leading downwards from the top of the building. The strips should be linked using palatinate. For copper, the palatinate should be riveted or doubled. If the outer surface of the strip is exposed, the lightning should reach the grounding system without damaging the conductors. In addition, the metal parts of buildings should be connected to the system of conductors. If this is not possible, the conductors should lead away from them. The strongest possible types of rivets and palatinate are prescribed as the types of jointing material for the system of conductors. A visual inspection at least once per year was also introduced for lightning conductors. It is important to locate the grounding system as close as possible to a source of water, or to place it deep into the ground. These rules were issued mainly to protect churches, stores of gunpowder, thatched roofs, windmills, cranes, carts and boats. The Belgian physicist Melsens [22] suggested placing conductors on all sides of a building.

On the basis of this initial experience, people began to think about constructing different types of lightning rods (e.g. the development of the Gay-Lussac lightning conductor, the Faraday cage, the Findeisen lightning conductor, the Zenger lightning rod, lightning conductors between the 1930s and 1950s, active lightning conductors, etc.) and about forming a background for uniform procedures for using lightning rods in practical applications. That is, they began to prepare legislative procedures.

The technical community in the Czech lands was regularly informed about extraordinary events (lightning strikes on buildings) during seminars of the Union of Judicial Experts (the UJE). Contributions to these meetings were also published, for example the IEC, EN and ČSN standards for lightning protection.

\section{STANDARDS FOR LIGHTNING PROTECTION}

\subsection{IEC, EN AND CSNN STANDARDS FOR LIGHTNING PROTECTION}

Most standards in the field of lightning protection are established by working groups of the IEC TC 81 international technical commission: Protection against Lightning.

An important role in the development of standards is played by the CIGRE scientific committee, which was established in the 1920s. In January 1921, the Union des Syndicats de l'Electricité de Paris, the Compagnie Générale d'Electricité de Paris, and the Société Suisse pour la Distribution Transport et de l'Electricité à Berne met on the initiative of two French electrical organizations and one Swiss organization. After consultations with the International Electrotechnical Commission, they set up CIGRE [CARAN Paris, Fonds Ernest Mercier - 98 AQ 6 dossier 3 - CIGRE]. This institution held its first meeting in Paris in November 1921. The reason for forming CIGRE was that the leaders of these institutions believed that energy consumption in manufacturing and in households was increasing. Europe therefore needed to coordinate electricity distribution for local and regional areas from an international perspective. Another issue was protection from lightning strikes.

Two important international institutions established their headquarters in Paris in the early 1920s: 
the Conférence Internationale des Grands Réseaux Electriques à Haute Tension - the International Conference of Large Electrical Networks (CIGRE) and the Union Internationale des Producteurs et Distributeurs d'Energie Electrique - the Union of Producers and Distributors of Electrical Energy (UNIPEDE). The CIGRE meetings were gradually formed into three separate sections. The first dealt with the production and transmission of electricity, the second with the construction of distribution networks, installations and overhead and underground lines and insulation, and the third dealt with the use of electrical power transmission, standardization, tariffs, distribution, protection and safety, and the promotion of electrification. Membership of the Czechoslovak Electrotechnical Association (CES, 1919-1951) in these organizations promised Czechoslovak experts the latest technical information and knowledge on the necessary standards.

The CIGRE scientific committee approves the text of standards based on the latest scientific knowledge. These standards are then submitted to the IEC-CENELEC for a parallel vote, and then they are approved by CENELEC, the European Committee for Electrotechnical Standardization. CENELEC members are obliged to comply with CEN/CENELEC Internal Regulations, which stipulate the conditions under which European standards shall become national standards without modification.

The series of Czech safety standards ČSN EN 623051 to 4 (valid from November 2006) [5]8], represents the safest option for protection against lightning and surges, and is based on scientific research and lightning measurements undertaken since the 1930s. The second editions of ČSN EN 62305-1, 3 and 4 [10-13] are currently valid. A second edition of part 2 of ČSN EN 62305 - Risk Management [14] was published in February 2013.

The standard ČSN 341390 - Electrical engineering regulations: Regulations for lightning protection [15] - was valid from the 1970s until February 2009. While it was in force, the standard provided a safe solution for protection against lightning. Over time, however, the standard became completely inadequate, due to the frequent introduction of sensitive electronic equipment in practical applications, and the gradual miniaturization of electronic systems.

During the period of co-existence (from November 2006 to February 2009) of the series of standards ČSN EN 62305-1 to 4 [5]8] and ČSN 341390 [15], economic considerations were unfortunately promoted at the expense of technical solutions. However, in this period, all projects had to be designed according to the ČSN EN 62305-1 to 4 standards [5-8].

\subsection{LightNing PROTECTION LEGISLATION VALID IN THE CZECH REPUBLIC}

From 1998 to 2009, Decree No. 137/1998 Coll. on general technical requirements for construction [16] was valid in the Czech Republic. Article 47 Protection against lightning defined the structures and facilities for which this protection must be established:

a) Risk to life or health (for example, residential buildings, buildings for large gatherings of people, buildings for trade, health and education, buildings for public accommodation) or risk to a large number of animals.

b) Failure with extensive consequences (for example, power plants, gasworks, waterworks, buildings for communications equipment, stations).

c) Explosions (for example, factories and warehouses for explosive and flammable materials, liquids and gases).

d) Damage to cultural or other treasures (for example, picture galleries, libraries, archives, museums, heritage-listed buildings).

e) Transfer of fire to neighboring buildings, which, according to letters a) to d) must be protected against lightning.

f) Buildings for which there is an increased risk of lightning due to their location on a hill or because they extend above their surroundings (for example, factory chimneys, towers, observation towers).

According to paragraph 3, letter p) of Decree No. 137/1998 Coll. [16] these requirements are met by Czech technical standard ČSN 341390 [15].

In the supplementary list II.A of selected Czech national standards relating to further requirements of Decree No. 137/1998 Coll. [16] organized by paragraphs, it is stated that standard CSN 341390 Electrical engineering regulations: Rules for lightning protection and lightning conductors [15] is applicable for the whole of paragraph 47 .

Decree No. 268/2009 Coll. on technical requirements for construction [4] has been valid since 2009 . According to this decree, a damage risk analysis must be performed for the following buildings according to standard values, see Article 36 :

a) danger to life or health, especially in residential buildings, buildings with an internal assembly space, buildings for trade, health and education, buildings for accommodation or buildings for a large number of animals,

b) failure with extensive consequences to public services, especially in power plants, gasworks, waterworks, buildings for communications equipment and stations,

c) explosions, especially in the manufacture and storage of explosive and flammable materials, liquids and gases,

d) damage to cultural heritage, or other treasures, especially in picture galleries, libraries, archives, museums, heritage-listed buildings, 
e) transfer of fire to neighboring buildings, which, according to letters a) to d) must be protected against lightning,

f) buildings for which there is an increased risk of lightning due to their location on a hill, or because they extend above their surroundings, especially factory chimneys, towers, observation towers and broadcast towers.

The standard value according to Article $3 . \mathrm{k}$ ) of this Decree [4] is understood to mean:

"A specific technical requirement, especially a limit value, a design method, nationally determined parameters, technical properties of building structures and technical equipment, contained in the relevant Czech technical standard, compliance with which shall be deemed to meet the requirements of the specific provisions of this Decree."

According to the below-mentioned opinion of the Ministry for Regional Development, for the purposes of this Decree this can be represented by the series of standards CSN EN 62305-1 to 4 ed. 2 [10 14].

\subsection{LightNING PROTECTION LEGISLATION VALID IN HUNGARY}

The first lightning protection standard in Hungary was published in 1937 [30. The standards have developed significantly since that time as a result of intensive research in the field. The probabilistic approach to lightning protection and the rolling sphere method was first described by Professor Horváth at the Budapest University of Technology in 1962 [31], and was introduced by the Hungarian standard for lightning protection 32 in the same year. This work improved on the results of Schwaiger, who in 1935 introduced a protected space bordered with a circular arc instead of straight lines 33. Professor Verebélÿ performed model experiments at the Budapest University of Technology in 1948, and on basis of this lowered the centers of the circles 34. These methods were mainly used for the construction of high voltage lines. We cannot yet speak of the rolling sphere method, because the radius that was applied was not constant. Although the values of the radius have varied over the years and in different countries, the rolling sphere method is nowadays used worldwide for designing the arrangement of air terminals 35. Hungary introduced the EN 62305 series on lightning protection in 2006, and a 2nd edition in 2010/2011. The standard was originally developed by IEC, and CENELEC approved it as a European standard. As a member country of the European Union since 2004, Hungary was required to introduce it as a national standard without any modification. After much development and several editions, the old Hungarian lightning protection standard MSZ 274 had finally to be withdrawn in 2009 .

Hungary had joined CENELEC in 2002, and the use of earlier compulsory standards became volun- tary. However, according to the European regulations, the specifications formulated in standards concerning safety have to be applied by government decree. In Hungary the decree of 28/2011. (IX. 6.) BM on the National Regulation of Fire Protection (OTSZ) applies to lightning protection. This decree introduces a new term: 'norm-like' and 'not norm-like' lightning protection. As a definition, 'norm-like' lightning protection refers to protection according to the valid MSZ EN 62305 standard, and 'not norm-like' lightning protection refers to protection according to the former Hungarian standards. The decree states that structures designed and constructed after 2011 shall be protected against lightning strikes according to 'norm-like' lightning protection. Structures built before 2011 can have 'not norm-like' lightning protection, provided that their function remains unchanged.

The main requirements of decree $28 / 2011$. (IX. 6.) $\mathrm{BM}$ are the following (not an exhaustive list):

a) as a result of risk calculation, the risk to human life must be lower than $10^{-5}$,

b) as a result of risk calculation, the risk to public services must be lower than $10^{-4}$,

c) the level of protection shall be in accordance with Table 1 in the case of different types of structures.

d) lightning protection shall be inspected during installation, after installation and periodically throughout the lifetime of the structure (every 3 or 6 years, according to the risk of fire).

It should be noted that the inspection of lightning protection systems is generally implemented and well organized, with a long tradition in Hungary. Supervisors have been educated and examined for decades in the framework of a high-quality vocational training system. An inspection report is required for the approval of lightning protection systems by the relevant authority. It is not compulsory to install lightning protection if the height of the ridge is less than $10 \mathrm{~m}$, and if:

a) a residential building contains only one living unit, or contains only residential units standing side-byside,

b) in the case of residential units that are one above the other, their ground area is not greater than $400 \mathrm{~m}^{2}$,

c) the structure is a communal building not more than $400 \mathrm{~m}^{2}$ in ground area.

As has been shown, the decree does not require the direct use of standards in Hungary, but specifies technical requirements based on scientifically verified knowledge. Compliance with the standard provides a convenient means for conforming with the specified requirements of the decree. However, it leaves open the possibility of using new solutions that meet these requirements. Consequently, the 


\begin{tabular}{lcc}
\hline \multicolumn{1}{c}{ Type of structure } & \multicolumn{2}{c}{ Protection level } \\
\cline { 2 - 3 } & $\begin{array}{c}\text { Lightning } \\
\text { protection level } \\
\text { (LPS) }\end{array}$ & $\begin{array}{c}\text { Class of coordinated } \\
\text { lightning protection } \\
\text { level (LPMS) }\end{array}$ \\
\hline Educational buildings & III & III-IV \\
\hline $\begin{array}{l}\text { Difficulty of evacuation (e.g. structures } \\
\text { with immobile persons, hospitals) }\end{array}$ & III & III-IV \\
\hline $\begin{array}{l}\text { Structures designed for cultural or sport } \\
\text { events with a high number of participants }\end{array}$ & IV & III-IV \\
\hline $\begin{array}{l}\text { Hotels, hostels (with capacities greater } \\
\text { than 50 persons) }\end{array}$ & III & III-IV \\
\hline High risk of fire (class A and B) & II & II \\
\hline
\end{tabular}

TABLE 1. Required protection levels for various types of structures. The numbering of the protection levels is according to EN 62305.

condition for new solutions in the field of lightning protection is to provide at least the specified protection level in a verified manner. This excludes the legal possibility of installing technically unsuitable lightning protection in Hungary only on an economical basis. If this is done, the lightning protection will fail the compulsory inspection after installation, and the authority therefore will not authorize its use.

\subsection{The opinions of AFFECTED Ministries ON THE ISSUE OF PROTECTION AGAINST LIGHTNING}

\subsubsection{Ministry for Regional Development of the Czech Republic (MRD)}

It is clear that under the provisions of Article 36, paragraphs 1 and 2 of Decree No. 268/2009 Coll. on technical requirements for construction 4 there is a requirement to provide lightning protection for specific cases referred to in points a) to f) (including buildings for education). For these buildings, risk management must be calculated in accordance with standard values. These are represented by the series of standards ČSN EN 62305-1 to 4 ed.2 [10 14]. According to Article 55, paragraph 2 of this Decree [4] references to normative values should be indicative in order not to hinder innovation, if it can be proven that the proposed solution will achieve at least the same or better technical parameters than if the Czech technical standards were followed.

\subsubsection{Ministry of Industry and Trade of the Czech Republic (MIT)}

Act No. 22/97 Coll. 17 is not used for the purposes of assessing components for lightning conductors. Act No. 102/2001 Coll. on general product safety [18] is applied, and after the components have been assembled, the lightning conductor becomes a restricted technical device pursuant to Decree No. 73/2010 Coll. [19.

\subsubsection{Office for Standards, Metrology and Testing (OSMT)}

The French NF C 17-102 1] and the Slovak STN 341391 2] national standards were not incorporated into the CSN system and the standards are not harmonized, and in the legal opinion of OSMT they cannot be used as a normative reference for the purposes of Decree No. 268/2009 Coll. 4. According to OSMT, the French NF C 17-102 [1] and Slovak STN 341391 2 national standard have not been incorporated into the ČSN system, and they are therefore not valid in the Czech Republic.

In the Czech Republic, lightning protection is designed according to the series of Czech safety regulatory standards ČSN EN 62305-1 to 4 ed. 2 [10 14, not only for the "classic" lightning rod but also for ESE active lightning conductors, because this series of standards does not distinguish between them. ESE conductors can be used within this series, but only as a lightning rod.

ČSN 331500 20] sets the procedures according to the applicable ČSN and regulations (reference to ČSN EN 62305-1 to 4 ed. 2 [10-14], see ČSN 331500 [20], alteration Z4: 2007). According to Article 6.1.2, the conclusion of the inspection report must state whether the design conforms to the standard applicable at the time of its establishment, and whether the components are in good working condition.

If the inspection finds any defect, the inspection report must mention which standard or regulation it is in conflict with or what the risk to safety is due to the defect.

\subsubsection{Opinion of the Subcommittee on Lightning Protection at TSC 97}

Based on the reports of the scientific committee of CIGRE from IEC 2010 and 2011 and document BT136/2010, the French NF C 17-102 [1] and Slovak STN 341391 2 national standards are at a lower technical level than the Czech technical safety stan- 

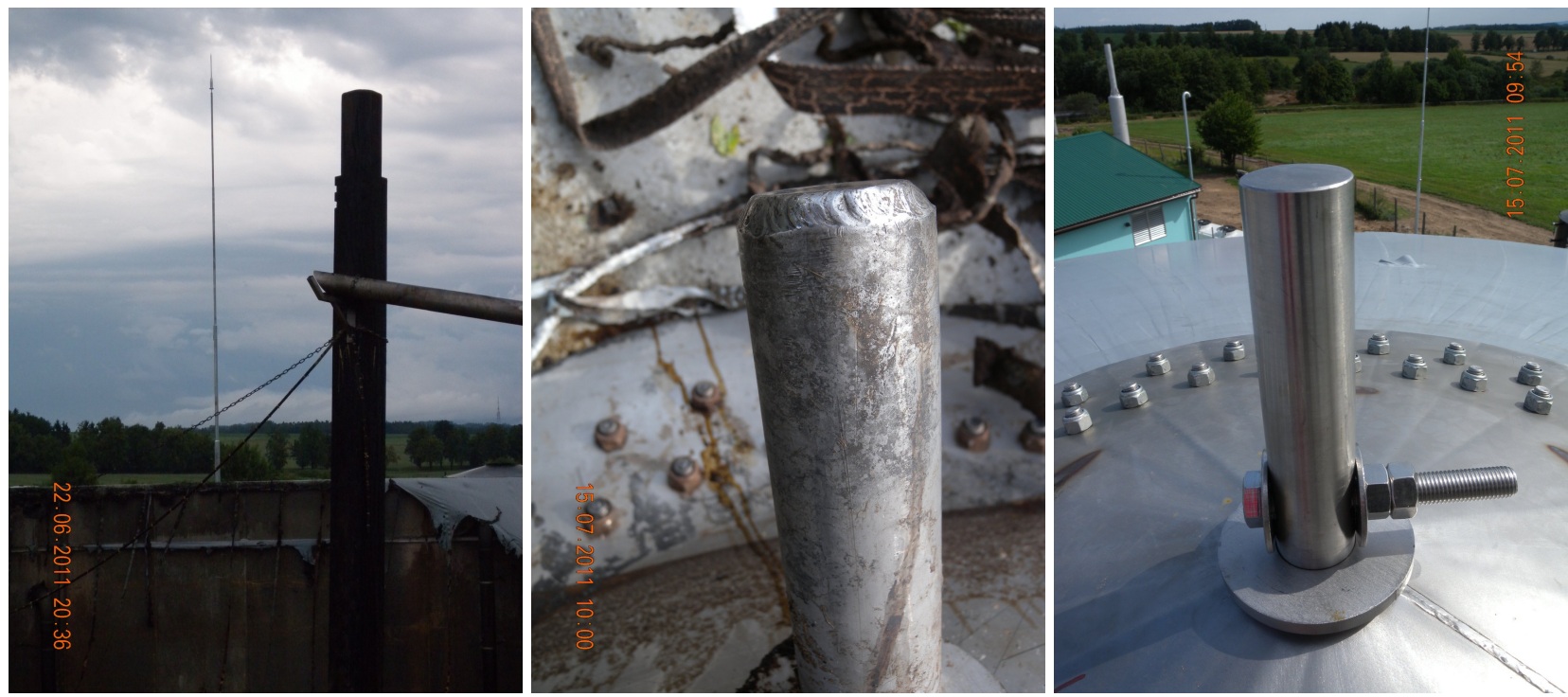

Figure 1. A lightning strike to a biogas plant digester, which was supposedly protected by an ESE conductor: demaged masking head after lightning strike (middle), new masking head before lightning strike (right).

dards ČSN EN 62305-1 to 2 ed. 2 Protection against lightning [10 14].

\subsection{French NATiOnAL STANDARD NF C 17-102 (2011)}

Based on extraordinary events that have taken place in the Czech Republic, it can be said that the French national standard NF C 17-102 [1] and the Slovak standard STN 341391 [2] are of a lower technical level than the Czech safety standards CSN EN 62305-1 to 4 ed. 1 and ed. 2 [10 14], especially in the following areas:

- During the design of protection zones for ESE active lightning conductors the speed of the responsive leader, which is much lower for ESE active lightning conductors, is not taken into account - the risk of lightning striking the protection zone of the conductor refers to an incident at the biogas plant in Malšice [29], cf. Fig. 1 .

- A sufficient distance between the lightning conductor and the internal installations cannot usually be observed - the risk of fire to the building refers to an extraordinary event in a brand new hotel building [28], cf. Fig. 2]

- Another case involves structural damage to a national monument, i.e. damage to the cultural heritage of the Czech Republic, protected by an active conductor, cf. Figs. 8-11.

According to the Czech technical safety standard ČSN EN 62305-3 ed. 2 [11, Article 5.2 and Annex A, ESE conductors can only be installed as lightning rods. Based on the opinion of OSMT, national standards NF C 17-102 [1] and STN 341391 [2] are not valid in the Czech Republic because they are in direct conflict with the European standard EN 62305-3 21] and thus with the Czech technical standard EN ed. 2 62305-3 [12, 13].

According to the opinion of the Subcommittee on Lightning Protection issued on the 27th of July 2012 at Technical Standards Committee 97 (a member of the Office for Standards, Metrology and Testing) based on CENELEC documents BT136/DG8043 DC, March 2010, CIGRE C4 COLLOQUIUM MAY 2010, WG C4.405, October 2011, the French national standard NF C 17-102 and the Slovak technical standard STN 341391 do not achieve the same protection as, or have higher technical parameters than, the Czech standard ČSN EN 62305-1 to 4. The French national standard NF C 17-102 and the Slovak technical standard STN 341391 have not been implemented into the system of Czech standards, they are not harmonized and cannot be used for a reference to standard values for the purposes of Decree No. 268/2009 Coll.

Lightning conductors are not evaluated by applying Act No. 22/1997 Coll. on technical requirements for products, because once a lightning rod has been assembled it becomes a dedicated technical device pursuant to Decree No. 73/2010 Coll. on the determination of dedicated electrical engineering devices, their classification and grouping and on detailed conditions for their safety. [26]

\section{Conclusions}

This article has analyzed the development of technical and legal considerations relating to protection against lightning. It has discussed the appropriate use and correct interpretation of standards. Examples have demonstrated the consequences of inappropriate and incorrect lightning protection.

The article has also attempted to identify the individual development steps that have led to the formulation of important legislation. It recounts not only 

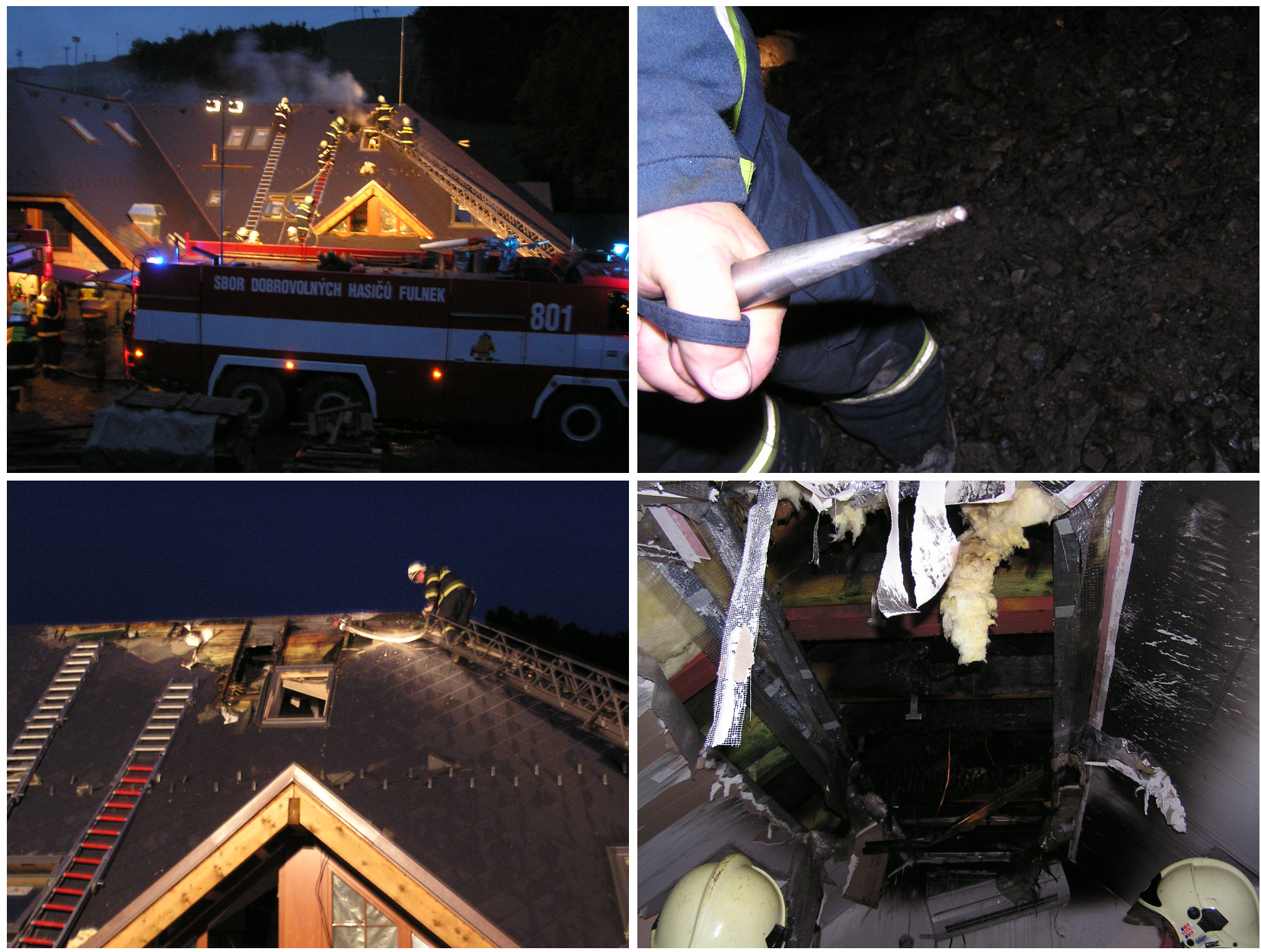

FIgURE 2. Fire at a hotel which was supposedly protected by an ESE conductor.

the results of the research of Václav Prokop Diviš and Benjamin Franklin, but also the first work of Reimarus from the late 18th century on the construction of buildings with lightning rods. It highlights the interest in this issue from the 1920s in the framework of CIGRE and the different types of lightning rods that have been used (e.g. the Gay-Lussac lightning conductor, the Faraday cage, the Findeisen lightning conductor, the Zenger lightning rod, lightning conductors from the 1930s and 1950s, active lightning conductors, etc.) The authors have avoided unnecessarily dwelling on technical considerations resolved in the past that are now being discussed again due to the use of unconventional conductors.

The paper has also dealt in detail with the schematics and regulation of lightning protection. It has focused on the technical and legal interpretation of standards and laws, and has offered a critical assessment of the accuracy of their use. We have demonstrated the physical properties of lightning which underline the arguments arising from the misinterpretation of rules, regulations and laws, including those from abroad.

This has been demonstrated on the basis of three examples of proven failure of unconventional lightning protection. The first concerns a fire at a biogas plant supposedly protected by an active lightning conductor, which was started by a direct lightning strike. The second example is of a fire in a newly-constructed hotel building supposedly protected by an ESE-type lightning conductor. The third example presents a lightning strike on a protected cultural heritage building. There are many examples of incorrectly selected protection against lightning (both conventional and unconventional). This has led to damage to buildings and danger to human life. Direct failure of ESE-type systems often cannot be proven. This is because objective outcomes are manipulated (e.g. lightning conductor heads are taken away to corporate laboratories, where the evidence is modified).

The topicality of this article underscores the numerous proven failures of active lightning protection. The article promotes the prevention of unnecessary loss of human life and damage to buildings by making appropriate technical decisions and complying with the laws and standards in the field of lightning conductors.

\section{ACKNOWLEDGEMENTS}

This work was supported by Czech Technical University in Prague and by the Budapest University of Technology and Economics. 

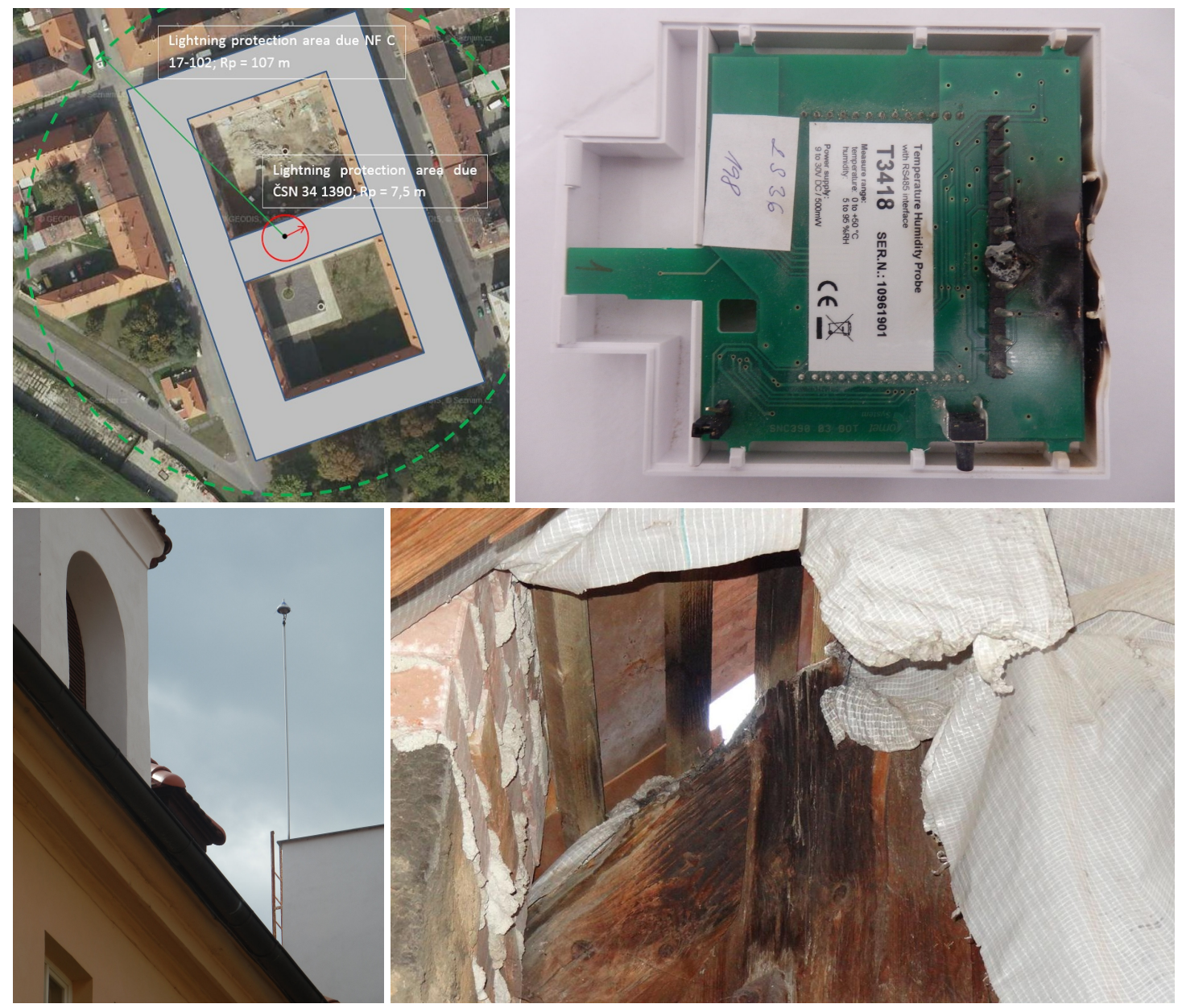

FIGURE 3. Fire at a hotel which was supposedly protected by an ESE conductor.

\section{REFERENCES}

[1] NF C 17-102; 1995: Protection of structures and of open areas against lightning using early streamer emission air terminals.

[2] STN 34 1391, 1998-06: Elektrotechnické předpisy: Výber a stavba elektrických zariadeni Ochrana pred bleskom. Aktivne bleskosvody.

[3] Act No. 183/2006 Coll., on town and country planning and the building code (Building Act).

[4] Decree No. 268/2009 Coll., on technical requirements for construction.

[5] EN 62305 - 1, 2006-11: Protection against lightning Part 1: General principles.

[6] EN 62305 - 2, 2006-11: Protection against lightning Part 2: Risk management.

[7] EN 62305 - 3, 2006-11: Protection against lightning Part 3: Physical damage to structures and life hazard.

[8] EN 62305 - 4, 2006-11: Protection against lightningPart 4: Electrical and electronic systems within structures.

[9] Kutáč, J.: Rozbor mimořádných událostí zpưsobených údery blesku v roce 2012, Seminar of UNIE SOUDNÍCH ZNALCŮ, 2012, ISBN 978-80-260-3382-0.

[10] EN 62305 - 1 ed. 2, 2011-09: Protection against lightning - Part 1: General principles.
[11] Chisholm, H. (ed.): Encyclopaedia Britannica. 11th ed. Cambridge University Press 1911.

[12] EN 62305 - 3, 2011-01: Protection against lightning Part 3: Physical damage to structures and life hazard.

[13] EN 62305 - 4, ed.2, 2011-09: Protection against lightning - Part 4: Electrical and electronic systems within structures.

[14] EN 62305 - 2, 2013: Protection against lightning Part 2: Risk management.

[15] ČSN 34 1390, 1969: Electrical engineering regulations: Rules for lightning protection and lightning conductors.

[16] Decree No. 137/2009 Coll., on general technical requirements for construction.

[17] Act No. 22/97 Coll., on technical requirements for products and on amendments to certain laws.

[18] Act No. 102/2001 Coll., on general product safety and on amendments to certain laws.

[19] Decree No. 73/2010 Coll., on the determination of dedicated electrical engineering devices, their classification and grouping and on detailed conditions for their safety (Decree on the determination of dedicated electrical engineering devices).

[20] ČSN 33 1500, 1990-06: Electrical engineering regulations. Inspection and testing of electrical installations. 
[21] EN 62305 - 3, 2006-02: Protection against lightningPart 3: Physical damage to structures and life hazard.

[22] Mikeš, J., Efmertová, M.: Elektřina na dlani: kapitoly z historie elektrotechniky $v$ českých zemích. Praha: Milpo media, 2008

[23] Franklin, B., Farrand, M. (eds.): The autobiography of Benjamin Franklin. San Marino: The Huntington Library, 1964

[24] Reimarus, J. A. H.: Ausführliche Vorschriften zur Blitz-Ableitung an allerley Gebäuden: aufs Neue geprüfet, und nach zuverlässigen Erfahrungen, in Hinsicht auf Sicherheit und Bequemlichkeit, entworfen; Mit zwey Kupfertafeln / von J. A. H. Reimarus, der Arzneygelahrtheit Doctor, der Naturlehre und Naturgeschichte Professor. Hamburg, 1797.

[25] Experiments and Observations on Electricity, Made at Philadelphia in America. London: E. Cave, 1751.

[26] O platnosti norem při navrhování, povolování a zřizování ochrany před bleskem na stavbách. Věstník Úradu pro technickou normlaizaci, metrologii a státní zkušebnictví, No. 1, p. 2, 2013.

[27] Peter Hasse, Johannes Wiesinger, Wolfgang Zischank. Handbuch für Blitzschutz und Erdung. PFLAUM 2006.

[28] Kutáč, J., Martínek, Z., Mikeš, J., Černoch, D.: A New Hotel "Protected" by Air-Termination System ESE Goes Up In Flames. Elektro. 2012, Vol. 22, No. 8-9, pp. $82-85$.
[29] Mikeš, J., Kutáč, J., Martínek, Z., Petrák, M.: Biogas plant explosion protected early streamer emission (ESE) air terminal. Elektro. 2011, Vol. 21, No. 11, pp. 23-26.

[30] MOSZ 274:1937, Safety guidelines to avoid the effects of destroying lightning.

[31] Horváth, T.: The probability theory of lightning protection. Elektrotechnika, Vol. 55, pp. 49-61, Budapest, 1962.

[32] MSZ 274:1962, Lightning protection.

[33] Schwaiger,A.: Der Schutzbereich von Blitzableitern. Oldenburg, München, 1938.

[34] Verebélÿ, L.: Experiment on the protective space of lightning rods and groundwires. Müegyetemi Közlemények, Vol. 3, pp. 1-20, Budapest 1948.

[35] Szedenik N.: Rolling Sphere: Method or Theory? (Journal of Electrostatics, 51-52/2001. pp. 345-350, Elsevier Science Publishers B.V., Amsterdam)

[36] Mikeš, J., Efmertová, M.: Development of lightning rod for lightning protection standard in Europe, especially in Czech lands. Journal of Electrostatics. 2013, Elsevier Science Publishers B.V., Amsterdam, vol. 71 , no. 3, pp. 597-601.

[37] Kutáč, J., Mikeš, J., Martínek, Z.: Ochrana před bleskem jimačem ESE a jeji vliv na ochranu kulturní památky. All for Power. 2013, AF POWER agency, a.s., Prague, vol. 7, no. 2, pp. 94-97. 